\title{
Photoreactions of (2-Acetoxyphenyl)pentamethyldisilane ${ }^{\dagger}$
}

\author{
Seung Ki Park* and Hyun A Kim \\ Department of Chemistry, College of Natural Sciences, The University of Suwon, Suwon 445-743, Korea \\ *E-mail: skpark@suwon.ac.kr \\ Received February 25, 2011, Accepted April 6, 2011
}

Key Words : (2-Acetoxyphenyl)pentamethyldisilane, Silene

It is well known that the photoreactions of aryldisilanes show four reaction patterns ${ }^{1}$ since the first report on the photolysis of phenylpentamethyldisilane and ( $p$-tolyl)pentamethyldisilane by Ishikawa et al. ${ }^{2}$ in 1975 : (path a) formation of a silene compound via elimination of a trimethylsilane ${ }^{3}$, (path b) formation of a silene compound arising from 1,3shift of trimethylsilyl radical, which is formed via homolytic cleavage of silicon-silicon bond ${ }^{4-9}$, (path c) formation of a trimethylsilyl compound via elimination of a silylene $e^{10,11}$, (path d) formation of a direct solvolysis compound via elimination of a trimethylalkoxysilane or pentamethylalkoxydisilane. ${ }^{12,13}$

Silenes having the $\mathrm{C}=\mathrm{Si}$ moiety are regarded as highly interesting intermediates. Consequently the synthesis and reactions of silenes as useful intermediates have been extensively investigated. ${ }^{14,15}$ The intermolecular reactions between highly unstable silenes and the compounds containing functional groups such as $\mathrm{OH}^{16-22}, \mathrm{C}=\mathrm{O}^{23-26}$, and $\mathrm{C}=\mathrm{C}^{27-31}$ bonds resulted in the formation of the addition products.

In connections with the photolysis of aryldisilanes, we recently disclosed the intramolecular reactions between the silene intermediates resulted from the photoreactions of ortho-substituted aryldisilanes and ortho-substituents to give the novel silicon-containing heterocyclic compounds such as the photoinduced intramolecular reactions of (2-substitutedphenyl)pentamethyldisilanes ${ }^{32}$, (2-alkoxymethylphenyl)pentamethyldisilanes ${ }^{33}, 2$-(pentamethyldisilanyloxy)phenylpentamethyldisilane $^{34}$ and (2-hydroxyethoxyphenyl)pentamethyldisilane. ${ }^{35}$ We have also investigated the synthesis of siliconcontaining heterocyclic compounds through the intramolecular reactions of silacyclopropene or 1-silaallene moiety with ortho-substituents in ortho-substituted-phenylethynylpentamethyldisilanes ${ }^{36}$.

As a part of our continuous studies utilizing the silenes as reaction intermediates for the synthesis of silicon-containing heterocyclic compounds, we investigated the photoreactions of (2-acetoxyphenyl)pentamethyldisilane which has the acetoxy group as ortho substituent to phenylpentamethyldisilane because it was expected that the novel photoproducts could be formed from the intramolecular reaction of ortho-substituted acetoxy group with the silene intermediate. In this note, we would like to report the detailed photochemical study of (2-acetoxyphenyl)pentamethyldisilane.

\footnotetext{
This paper is dedicated to Professor Eun Lee on the occasion of his ho-
} nourable retirement.
The starting (2-acetoxyphenyl)pentamethyldisilane 2 was prepared from the reaction of (2-hydroxyphenyl)pentamethyldisilane $\mathbf{1}^{35}$ with acetyl chloride using triethylamine as base in tetrahydrofuran at room temperature (Scheme 1).

In order to investigate a possibility that the $\mathrm{C}=\mathrm{O}$ bond as ortho substituent in $\mathbf{2}$ reacts intramolecularly with a silene, the photolysis of $\mathbf{2}$ was performed.

Irradiation of 2 in deaerated benzene with $254 \mathrm{~nm}$ UV light afforded two photo-Fries rearrangement products 4 (18\% yield) and 5 (10\% yield) along with some decomposition products of unknown structure as shown in Scheme 1. ${ }^{37,38}$

However, when $90 \%$ of $\mathbf{2}$ was photolyzed the expected reaction of the $\mathrm{C}=\mathrm{O}$ bond in o-acetoxy group with $\mathrm{C}=\mathrm{Si}$ bond of silene intermediate in $\mathbf{3}$ arising from 1,3-migration of trimethylsilyl radical via homolytic cleavage of siliconsilicon bond in the pentamethyldisilanyl group of the photoexcited state of $\mathbf{2}$ to the $\mathrm{C}_{6}$ position of benzene ring to give the compound $\mathbf{6}$ was not observed in this photoreaction. In relation to the photolysis of ortho-substituted aryldisilane, we found that the photoreaction of (2-allyloxyphenyl)pentamethyldisilane $^{32}$ in benzene gave a novel intramolecular photoproduct through the reaction between the silene intermediate and ortho-substituent, allyloxy group. The photolysis of (2-hydroxymethylphenyl)pentamethyldisilane ${ }^{33}$ and (2acetoxymethylphenyl)pentamethyldisilane ${ }^{33}$ also afforded a novel intramolecular photoproducts via silene intermediates. In contrast to the photoreaction of (2-allyloxyphenyl)pentamethyldisilane or (2-hydroxymethylphenyl)pentamethyldisilane, desired product $\mathbf{6}$ via the silene intermediate was not

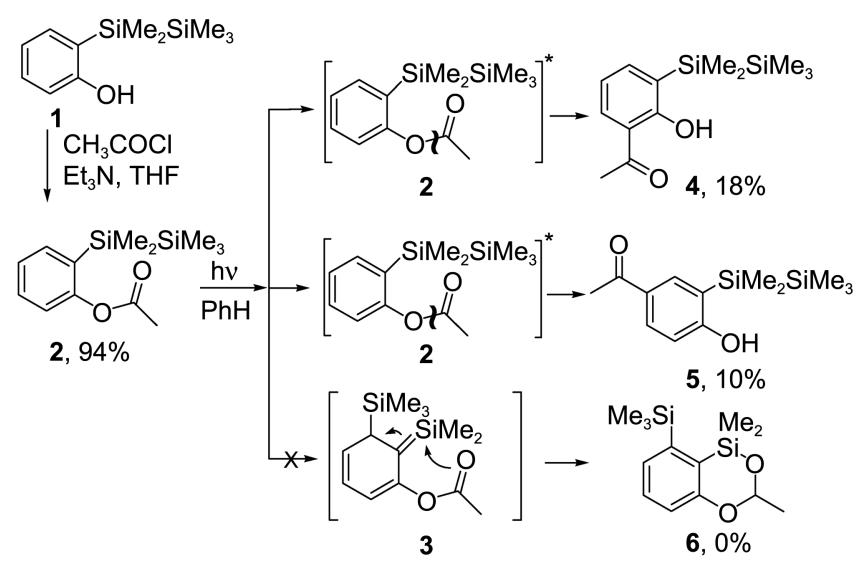

Scheme 1 
detected in the photolysis of $\mathbf{2}$ in deaerated benzene. This observation clearly indicated that the photo-Fries rearrangement reaction is faster than the silene formation in this photoreaction.

The structures of these photoproducts $\mathbf{4}$ and $\mathbf{5}$ were determined by various physical methods. The photoproducts 4 and $\mathbf{5}$ can be distinguished by the proton resonances in the phenyl region and $\mathrm{OH}$ peak in ${ }^{1} \mathrm{H}-\mathrm{NMR}$. The ${ }^{1} \mathrm{H}-\mathrm{NMR}$ spectrum of 4 shows the 1,2,3-trisubstituted benzene structure and $\mathrm{OH}$ peak at $12.53 \mathrm{ppm}$, but 5 shows the 1,3,4-trisubstituted benzene structure and $\mathrm{OH}$ peak at $1.26 \mathrm{ppm}$. Appearing at $12.53 \mathrm{ppm}$ is a result of the intramolecular hydrogen bonding between the carbonyl group and the hydroxyl group in 4.

Irradiation of 2 in deaerated methanol with $254 \mathrm{~nm} \mathrm{UV}$ light gave three photoproducts $7, \mathbf{1}$, and $\mathbf{8}(9,18$, and $21 \%$ yield, respectively) along with some decomposition products as shown in Scheme 2 . When $97 \%$ of 2 was photolyzed the expected photoproducts from the reaction of the silene intermediate with the $\mathrm{C}=\mathrm{O}$ bond as ortho-substituent were not obtained, indicating that the photolysis of $\mathbf{2}$ did not give the silene intermediate in methanol solvent.

Compound 7 was probably formed from the nucleophilic attack at $\beta$ silicon atom of pentamethyldisilanyl group in the photoexcited state of 2 by methanol and the photo-Fries rearrangement of the acetyl group in $\mathbf{2}$ to the $\mathrm{C}_{5}$ position of benzene ring. Compound $\mathbf{1}$ was formed from the methanolysis of the acetoxy group as ortho-substituent group in $\mathbf{2}$. The formation of phenol $\mathbf{8}$ was explained by $\alpha$ silicon atom attack of pentamethyldisilanyl group in the photoexcited state of 2 by methanol and the methanolysis of the acetoxy group in 2.

The ${ }^{1} \mathrm{H}-\mathrm{NMR}$ and IR absorption spectra of 7 show a septet resonance at $4.50 \mathrm{ppm}$ and a characteristic absorption at $2112.6 \mathrm{~cm}^{-1}$, respectively, due to a $\mathrm{Si}-\mathrm{H}$ proton and a $\mathrm{Si}-\mathrm{H}$ stretching mode in the dimethylsilyl group of 7 .

In contrast to the photolysis of $\mathbf{2}$ in a deaerated benzene, the photolysis of $\mathbf{2}$ in a deaerated methanol provided more methanolysis products $\mathbf{1}$ and $\mathbf{8}$ than the photo-Fries rearrangement product 7 , indicating that the methanolysis reaction about the acetoxy group in $\mathbf{2}$ is much more reactive than the

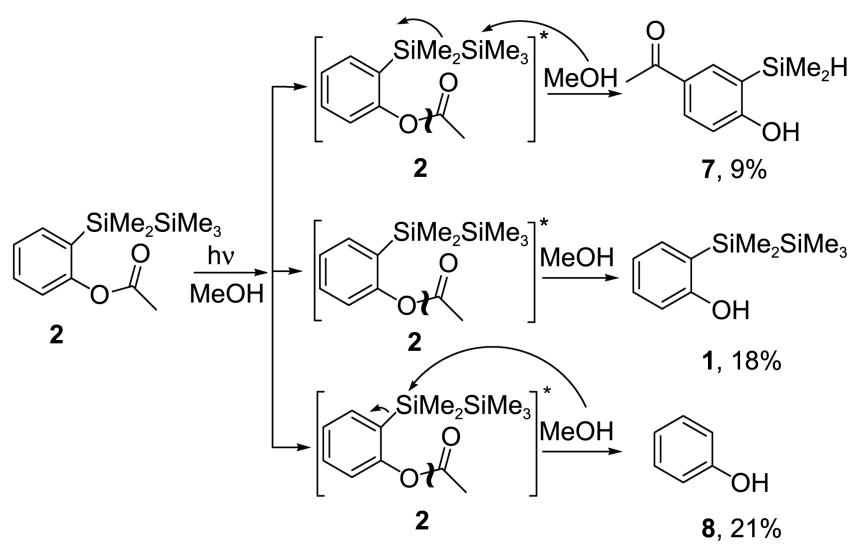

Scheme 2
photo-Fries rearrangement reaction in methanol solvent.

In conclusion, the photoreaction of $\mathbf{2}$ in a deaerated benzene provided $\mathbf{4}$ and $\mathbf{5}$ via a photo-Fries rearrangement reaction but the expected photoproduct from the intramolecular reaction between the $\mathrm{C}=\mathrm{Si}$ moiety and ortho-substituent, $\mathrm{C}=\mathrm{O}$ group was not obtained. The photolysis of $\mathbf{2}$ in a deaerated methanol gave a photoproduct 7 via $\beta$ silicon atom attack of pentamethyldisilanyl group by methanol and the photo-Fries rearrangement and compounds $\mathbf{1}$ and $\mathbf{8}$ but the expected photoproducts from the silene intermediate was also not obtained in this photoreaction.

\section{Experimental}

Synthesis of (2-Acetoxyphenyl)pentamethyldisilane 2 . Triethylamine $(0.46 \mathrm{~mL}, 3.3 \mathrm{mmol})$ was added to a solution of (2-hydroxyphenyl)pentamethyldisilane 1 ( $0.5 \mathrm{~g}, 2.2 \mathrm{mmol})$ in tetrahydrofuran $(20 \mathrm{~mL})$ at $0{ }^{\circ} \mathrm{C}$ under nitrogen atmosphere. Acetyl chloride $(0.3 \mathrm{~mL}, 4.4 \mathrm{mmol})$ was added dropwise to the resulting solution and the mixture was stirred at room temperature for $2 \mathrm{~h}$. Water $(30 \mathrm{~mL})$ was added to the solution and extracted with ethyl acetate $(3 \times 10 \mathrm{~mL})$. The combined ethyl acetate solution was washed with water $(20 \mathrm{~mL})$, brine $(20 \mathrm{~mL})$ and dried $\left(\mathrm{MgSO}_{4}\right)$. The solvent was evaporated in vacuo to give the crude product. Flash column chromatography with n-hexane/ethyl acetate $(5 / 1, \mathrm{v} / \mathrm{v})$ as an eluent gave 2 (0.56 g, 94\% yield) as a colorless oil; ${ }^{1} \mathrm{H}-\mathrm{NMR}$ $\left(\mathrm{CDCl}_{3}, 300 \mathrm{MHz}\right) \delta_{\mathrm{H}} 0.09(9 \mathrm{H}, \mathrm{s}), 0.35(6 \mathrm{H}, \mathrm{s}), 2.32(3 \mathrm{H}$, s), $7.08(1 \mathrm{H}, \mathrm{dd}, J=7.5,1.5 \mathrm{~Hz}), 7.22(1 \mathrm{H}, \mathrm{td}, J=7.5,1.5$ $\mathrm{Hz}), 7.38(1 \mathrm{H}, \mathrm{td}, J=7.5,1.5 \mathrm{~Hz}), 7.44(1 \mathrm{H}, \mathrm{dd}, J=7.5,1.5$ $\mathrm{Hz}) ;{ }^{13} \mathrm{C}-\mathrm{NMR}\left(\mathrm{CDCl}_{3}, 75 \mathrm{MHz}\right) \delta_{\mathrm{C}}-3.35,-1.78,21.8,122.1$, 125.7, 130.1, 130.9, 135.6, 155.6, 169.7; UV $\left(\mathrm{CH}_{2} \mathrm{Cl}_{2}\right) \lambda_{\max }$ $274 \mathrm{~nm}$; FT-IR (NaCl) 3066.1, 2952.4, 2895.4, 1768.1, 1246.8, $1179.5,1074.5,834.1 \mathrm{~cm}^{-1}$; MS (70 eV) $\mathrm{m} / z 266\left(\mathrm{M}^{+}\right)$; MS $m / z(\%) 266\left(\mathrm{M}^{+}, 1.3\right), 251(30), 227$ (15), 209 (50), 193 (100), 151 (14), 73 (16); HRMS $\left(\mathrm{M}^{+}\right)$calcd for $\mathrm{C}_{13} \mathrm{H}_{22} \mathrm{O}_{2} \mathrm{Si}_{2}$ 266.1158 , found 266.1182 .

Irradiation of (2-Acetoxyphenyl)pentamethyldisilane 2 in benzene. A solution $\left(5 \times 10^{-4} \mathrm{M}\right)$ of (2-acetoxyphenyl) pentamethyldisilane $2(133 \mathrm{mg})$ in benzene $(1 \mathrm{~L})$ was deaerated by nitrogen purging for $30 \mathrm{~min}$ and irradiated in a Rayonet photochemical reactor, model RPR-208, equipped with RUL $254 \mathrm{~nm}$ lamps. After irradiation for $2.5 \mathrm{~h}$, the resulting photoreaction mixture was concentrated in vacuo. The photoproducts 4 and 5 were isolated in $24 \mathrm{mg}$ (18\% yield) and $13 \mathrm{mg}$ (10\% yield), respectively, in addition to $13 \mathrm{mg}$ (10\% yield) of the starting compound 2 by column chromatography with $n$-hexane/ethyl acetate $(5 / 1, \mathrm{v} / \mathrm{v})$ as an eluent followed by normal phase HPLC using $n$-hexane/ethyl acetate $(3 / 1, \mathrm{v} / \mathrm{v})$ as an eluent.

4: ${ }^{1} \mathrm{H}-\mathrm{NMR}\left(\mathrm{CDCl}_{3}, 300 \mathrm{MHz}\right) \delta_{\mathrm{H}} 0.053(9 \mathrm{H}, \mathrm{s}), 0.33$ $(6 \mathrm{H}, \mathrm{s}), 2.63(3 \mathrm{H}, \mathrm{s}), 6.88(1 \mathrm{H}, \mathrm{t}, J=7.5 \mathrm{~Hz}), 7.53(1 \mathrm{H}, \mathrm{dd}$, $J=7.5,1.5 \mathrm{~Hz}), 7.72(1 \mathrm{H}, \mathrm{dd}, J=7.5,1.5 \mathrm{~Hz}), 12.53(1 \mathrm{H}$, s); ${ }^{13} \mathrm{C}-\mathrm{NMR}\left(\mathrm{CDCl}_{3}, 75 \mathrm{MHz}\right) \delta_{\mathrm{C}}-3.77,-1.72,29.8,118.9$, 129.4, 131.5, 137.1, 142.3, 166.8, 204.9; UV $\left(\mathrm{CH}_{2} \mathrm{Cl}_{2}\right) \lambda_{\max }$ 257, $335 \mathrm{~nm}$; FT-IR (NaCl) 3456.1, 2952.5, 2926.5, 1634.4, $1410.7,1242.9,835.1 \mathrm{~cm}^{-1}$; MS (70 eV) $\mathrm{m} / z 266\left(\mathrm{M}^{+}\right)$; MS 
$m / z(\%) 266\left(\mathrm{M}^{+}, 23\right), 265$ (93), 251 (66), 211 (23), 193 (68), 149 (100), 131 (15), 73 (14); HRMS $\left(\mathrm{M}^{+}\right)$calcd for $\mathrm{C}_{13} \mathrm{H}_{22} \mathrm{O}_{2} \mathrm{Si}_{2} 266.1158$, found 266.1104.

5: ${ }^{1} \mathrm{H}-\mathrm{NMR}\left(\mathrm{CDCl}_{3}, 300 \mathrm{MHz}\right) \delta_{\mathrm{H}} 0.065(9 \mathrm{H}, \mathrm{s}), 0.37$ $(6 \mathrm{H}, \mathrm{s}), 1.26(1 \mathrm{H}, \mathrm{s}), 2.55(3 \mathrm{H}, \mathrm{s}), 6.74(1 \mathrm{H}, \mathrm{d}, J=8.4 \mathrm{~Hz})$, $7.85(1 \mathrm{H}, \mathrm{dd}, J=8.4,2.4 \mathrm{~Hz}), 7.97(1 \mathrm{H}, \mathrm{d}, J=2.4 \mathrm{~Hz}) ;{ }^{13} \mathrm{C}-$ $\mathrm{NMR}\left(\mathrm{CDCl}_{3}, 75 \mathrm{MHz}\right) \delta_{\mathrm{C}}-3.28,-1.31,26.8,114.5,126.1$, 130.4, 132.1, 137.2, 165.5, 198.2; UV $\left(\mathrm{CH}_{2} \mathrm{Cl}_{2}\right) \lambda_{\max } 269$ nm; FT-IR (NaCl) 3327.6, 2956.3, 1657.5, 1576.5, 1252.5, $832.1 \mathrm{~cm}^{-1}$; MS (70 eV) m/z $266\left(\mathrm{M}^{+}\right)$; MS m/z (\%) 266 (M+28), 265 (100), 249 (14), 225 (23), 193 (42), 149 (21), 73 (9); HRMS $\left(\mathrm{M}^{+}\right)$calcd for $\mathrm{C}_{13} \mathrm{H}_{22} \mathrm{O}_{2} \mathrm{Si}_{2} 266.1158$, found 266.1131 .

Irradiation of (2-Acetoxyphenyl)pentamethyldisilane 2 in methanol. A solution $\left(5 \times 10^{-4} \mathrm{M}\right)$ of (2-acetoxyphenyl) pentamethyldisilane $2(133 \mathrm{mg}$ ) in methanol (1 L) was deaerated by nitrogen purging for $30 \mathrm{~min}$ and irradiated in a Rayonet photochemical reactor, model RPR-208, equipped with RUL $254 \mathrm{~nm}$ lamps. After irradiation for $1 \mathrm{~h}$, the resulting photoreaction mixture was concentrated in vacuo. The photoproducts 7, 1 and 8 (phenol) were isolated in $9 \mathrm{mg}(9 \%$ yield), $20 \mathrm{mg}$ (18\% yield) and $10 \mathrm{mg}$ (21\% yield), respectively, in addition to $4 \mathrm{mg}$ ( $3 \%$ yield) of the starting compound 2 by column chromatography with $n$-hexane/ethyl acetate $(5 / 1, \mathrm{v} / \mathrm{v})$ as an eluent followed by normal phase HPLC using $n$-hexane/ethyl acetate( $3 / 1, \mathrm{v} / \mathrm{v})$ as an eluent.

7: ${ }^{1} \mathrm{H}-\mathrm{NMR}\left(\mathrm{CDCl}_{3}, 300 \mathrm{MHz}\right) \delta_{\mathrm{H}} 0.39(6 \mathrm{H}, \mathrm{d}, J=3.6$ $\mathrm{Hz}), 1.25$ (1H, s), $2.58(3 \mathrm{H}, \mathrm{s}), 4.50(1 \mathrm{H}$, septet, $J=3.6 \mathrm{~Hz})$, $6.82(1 \mathrm{H}, \mathrm{d}, J=8.7 \mathrm{~Hz}), 7.91(1 \mathrm{H}, \mathrm{dd}, J=8.7,2.1 \mathrm{~Hz}), 8.07$ $(1 \mathrm{H}, \mathrm{d}, J=2.1 \mathrm{~Hz}) ;{ }^{13} \mathrm{C}-\mathrm{NMR}\left(\mathrm{CDCl}_{3}, 75 \mathrm{MHz}\right) \delta_{\mathrm{C}}-3.92$, $26.5,114.5,123.4,129.8,132.6,137.5,165.5,198.1$; UV $\left(\mathrm{CH}_{2} \mathrm{Cl}_{2}\right) \lambda_{\max } 267 \mathrm{~nm}$; FT-IR (NaCl) 3674.7, 3120.3, 2962.1, 2112.6, 1649.8, 1561.1, 1353.8, 1260.3, $881.3 \mathrm{~cm}^{-1}$; MS (70 eV) $m / z 194\left(\mathrm{M}^{+}\right)$; MS m/z (\%) $194\left(\mathrm{M}^{+}, 19\right), 193$ (100), 169 (9), 149 (13), 135 (17); HRMS $\left(\mathrm{M}^{+}\right)$calcd for $\mathrm{C}_{10} \mathrm{H}_{14} \mathrm{O}_{2} \mathrm{Si}$ 194.0763, found 194.0711.

\section{References}

1. Kira, M.; Miyazawa, T.; Sugiyama, H.; Yamaguchi, M.; Sakurai, H. J. Am. Chem. Soc. 1993, 115, 3116.

2. Ishikawa, M.; Fuchikami, T.; Sugaya, T.; Kumada, M. J. Am. Chem. Soc. 1975, 97, 5923.

3. Nate, K.; Ishikawa, M.; Ni, H.; Watanabe, H.; Saheki, Y. Organometallics 1987, 6, 1673.

4. Ishikawa, M.; Fuchikami, T.; Kumada, M. J. Organomet. Chem. 1976, 118, 139.
5. Ishikawa, M.; Fuchikami, T.; Kumada, M. Tetrahedron Lett. 1976, 1299.

6. Ishikawa, M.; Fuchikami, T.; Kumada, M. J. Organomet. Chem. 1978, 162, 223.

7. Ishikawa, M.; Oda, M.; Miyoshi, N.; Fabry, L.; Kumada, M.; Yamabe, T.; Akagi, K.; Fukui, K. J. Am. Chem. Soc. 1979, 101, 4612.

8. Ohshita, J.; Ohsaki, H.; Ishikawa, M.; Tachibana, A.; Kurosaki, Y.; Yamabe, T.; Minato, A. Organometallics 1991, 10, 880.

9. Ohshita, J.; Ohsaki, H.; Ishikawa, M. Organometallics 1991, 10, 2695.

10. Ishikawa, M. Pure Appl. Chem. 1978, 50, 11.

11. Kira, M.; Sakamoto, K.; Sakurai, H. J. Am. Chem. Soc. 1983, 105, 7469.

12. Okinoshima, H.; Weber, W. P. J. Organomet. Chem. 1978, 149, 279.

13. Park, S. K. Bull. Korean Chem. Soc. 2007, 28, 1045.

14. Park, S. K.; Gong, S. Y. Bull. Korean Chem. Soc. 2010, 31, 731.

15. Ishikawa, M.; Fuchikami, T.; Kumada, M. J. Organomet. Chem. 1977, 127, 261.

16. Ishikawa, M.; Fuchikami, T.; Kumada, M. J. Organomet. Chem. 1976, 118, 155.

17. Morkin, T. L.; Leigh, W. J. Acc. Chem. Res. 2001, 34, 129.

18. Leigh, W. J.; Sluggett, G. W. J. Am. Chem. Soc. 1994, 116, 10468. 19. Steinmetz, M. G. Chem. Rev. 1995, 95, 1527.

20. Takaki, K.; Sakamoto, H.; Nishimura, Y.; Sugihara, Y.; Ishikawa, M. Organometallics 1991, 10, 888.

21. Ohshita, J.; Ohsaki, H.; Ishikawa, M.; Tachibana, A.; Kurosaki, Y.; Yamabe, T.; Tsukihara, T.; Takahashi, K.; Kiso, Y. Organometallics 1991, 10, 2685.

22. Ishikawa, M.; Nishimura, Y.; Sakamoto, H. Organometallics 1991, 10, 2701.

23. Ishikawa, M.; Fuchikami, T.; Kumada, M. J. Organomet. Chem. 1977, 133, 19 .

24. Ohshita, J.; Niwa, H.; Ishikawa, M. Organometallics 1996, 15, 4632.

25. Toltl, N. P.; Leigh, W. J. Organometallics 1996, 15, 2554.

26. Leigh, W. J.; Sluggett, G. W. Organometallics 1994, 13, 269.

27. Ishikawa, M.; Sakamoto, H.; Kanetani, F.; Minato, A. Organometallics 1989, 8, 2767.

28. Sakurai, H. J. Organomet. Chem. 1980, 200, 261.

29. Guselnikov, L. E.; Nametkin, N. S. Chem. Rev. 1979, 79, 529.

30. Ohshita, J.; Niwa, H.; Ishikawa, M.; Yamabe, T.; Yoshii, T.; Nakamura, K. J. Am. Chem. Soc. 1996, 118, 6853.

31. Sakurai, H.; Nakadaira, Y.; Kira, M.; Sugiyama, H.; Yoshida, K.; Takiguchi, T. J. Organomet. Chem. 1980, 184, C36.

32. Park, S. K. J. Photochem. Photobiol. A: Chem. 2005, 173, 29.

33. Park, S. K. Bull. Korean Chem. Soc. 2006, 27, 1305.

34. Park, S. K. Bull. Korean Chem. Soc. 2008, 29, 1018.

35. Park, S. K.; Seong, W. J. Bull. Korean Chem. Soc. 2009, 30, 1331.

36. Park, S. K.; Baek, D. J. J. Photochem. Photobiol. A: Chem. 2004, 163,87 and references cited therein.

37. Anderson, J. C.; Reese, C. B. Proc. Chem. Soc. 1960, 217.

38. Anderson, J. C.; Reese, C. B. J. Chem. Soc. 1963, 1781. 